Case Report

\title{
Histopathological and Immunohistochemical Characterization of Spontaneously Occurring Uterine Deciduomas in Young Adult Rats
}

\author{
Katsuhiko Yoshizawa $^{1 *}$, Yuko Emoto ${ }^{1,2}$, Yuichi Kinoshita ${ }^{1,2}$, Ayako Kimura ${ }^{1}$, Norihisa Uehara ${ }^{1}$, \\ Takashi Yuri ${ }^{1}$, Nobuaki Shikata ${ }^{2}$, and Airo Tsubura ${ }^{1}$ \\ ${ }^{1}$ Department of Pathology II, Kansai Medical University, 10-15 Fumizono, Moriguchi, Osaka 570-8506, Japan \\ ${ }^{2}$ Division of Pathology, Kansai Medical University Takii Hospital, 10-15 Fumizono, Moriguchi, Osaka 570-8507, Japan
}

\begin{abstract}
Uterine deciduomas were found in two female virgin rats, a 15-week-old Lewis rat and a 7-week-old Sprague-Dawley rat. The firm white nodules were located at the base of unilateral uterine horns and were approximately $6 \mathrm{~mm}$ and $4 \mathrm{~mm}$ in diameter. Histopathologically, the nodules were composed of three areas, each with a distinct type of proliferating cells: large epithelioid decidual cells with round nuclei, prominent nucleoli and abundant eosinophilic cytoplasm (antimesometrial region); compact spindle-shaped cells with oval nuclei and vacuolar cytoplasm (transitional region); and pleomorphic and spiny cells with round to oval nuclei and compact eosinophilic cytoplasm (mesometrial region). These cells proliferated in sheet-like arrangements and transformed into the other types of cells located in surrounding regions. Immunohistochemically, proliferating cells in all regions were strongly positive for proliferating cell nuclear antigen. The proliferating cells were positive for vimentin, and large decidual cells were positive for common acute lymphoblastic leukemia antigen 10, a marker of uterine interstitial cells. Large decidual cells were positive for $\alpha$-smooth muscle actin and desmin, suggesting differentiation into muscular cells. Progesterone receptor was expressed in all cell types; however, estrogen receptor $\alpha$ was not expressed in the antimesometrial region. These extremely rare tumor-like nodules represent nonneoplastic lesions referred as decidual reactions of endometrial interstitial cells, and their biological behavior is that of a space-occupying benign tumor in young rats. Our cases might provide information as a historical control in toxicity and pharmacological studies in rats. (DOI: 10.1293/ tox.26.61; J Toxicol Pathol 2013; 26: 61-66)
\end{abstract}

Key words: deciduoma, decidual reaction, immunohistochemistry, rat, uterus

Spontaneous primary tumors and tumor-like lesions of the rodent uterus are extremely rare in young rodents. Hyperplastic lesions of decidual stromal cells, so-called decidual reactions/decidual tumors, have been found in the uterus or subserosal abdominal locations in rats ${ }^{1,2}$, mice $^{3,4}$, guinea pigs $^{5}$, rabbits $^{6}, \operatorname{dogs}^{7}$, monkeys $^{8}$, and humans ${ }^{9,10}$. These lesions are characterized by focally extensive areas of hyperplastic and hypertrophied eosinophilic, round, oval to somewhat elongated cells, which are thought to be endometrial stromal cells. Decidual stromal cells are derived from the fibroblast-like cells within the endometrium, which maintain their progesterone receptors in the presence of progesterone $^{11}$. This proliferating lesion is often referred to as deciduoma and is thought to be a proliferative response of stromal endometrial cells that is histologically similar to decidual implantation sites ${ }^{2}$. This change is infrequently seen in young adult rats used in subacute toxicity studies, and the

Received: 21 October 2012, Accepted: 22 November 2012

*Corresponding author: K Yoshizawa (e-mail: yoshizak@takii.kmu. ac.jp)

(C2013 The Japanese Society of Toxicologic Pathology

This is an open-access article distributed under the terms of the Creative Commons Attribution Non-Commercial No Derivatives (by-ncnd) License $<$ http://creativecommons.org/licenses/by-nc-nd/3.0/>. incidence of decidual reactions/deciduoma in young female F344 rats examined in National Toxicity Program studies is $1.3 \%$ (2 of 159 rats) $)^{12}$. Only 5 spontaneous cases of decidual reactions/deciduoma were identified in approximately 12000 Sprague-Dawley (SD) rats at 3- to 8-months of age ${ }^{13}$. In B6C3F1 mice used in National Toxicity Program studies, this change was seen in only one mouse ${ }^{3}$. Few studies on the immunohistochemical characterization of spontaneously occurring deciduoma have been reported ${ }^{13}$. We encountered two uterine deciduomas in a young Lewis rat and a SD rat and examined their histopathological and immunohistochemical features in the present study.

The experimental protocol and all animal procedures were approved by the Animal Care and Use Committee of Kansai Medical University and were in accordance with the university's guidelines for animal experimentation. Case 1 was a 15 -week-old female LEW/CrlCrlj (Lewis) rat, and Case 2 was a 7-week-old female Crl:CD (SD) rat. The 2 rats were purchased from Charles River Laboratories Japan (Kanagawa, Japan) and used in different mechanistic studies of chemical-induced toxicity and carcinogenesis. The rats were housed in plastic cages with paper-chip bedding (Paper Clean, SLC, Hamamatsu, Japan) in an air-conditioned room at $22 \pm 2{ }^{\circ} \mathrm{C}$ and $60 \pm 10 \%$ relative humidity with a 12-h light/dark cycle and fed a commercial diet (CMF 30 
Table 1. Primary Antibodies and Reaction Conditions for Immunohistochemistry

\begin{tabular}{|c|c|c|c|c|c|}
\hline Primary antibody ${ }^{1)}$ & Source ${ }^{2)}$ & Clone & Dilution $^{3)}$ & Antigen retrieval ${ }^{4)}$ & Detection \\
\hline PCNA & Leica & $\mathrm{PC} 10$ & $1: 100$ & $115^{\circ} \mathrm{C}$ for $10 \mathrm{~min}$ & Proliferating cells \\
\hline Pancytokeratin & Dako & AE1/AE3 & $1: 50$ & $115^{\circ} \mathrm{C}$ for $10 \mathrm{~min}$ & Epithelial cells \\
\hline Vimentin & Dako & V9 & $1: 50$ & $115^{\circ} \mathrm{C}$ for $10 \mathrm{~min}$ & Mesenchymal cells \\
\hline CD10 & Novocastra & $56 \mathrm{C} 6$ & $1: 100$ & $115^{\circ} \mathrm{C}$ for $10 \mathrm{~min}$ & Uterine interstitial cells \\
\hline SMA & Dako & $1 \mathrm{~A} 4$ & $1: 500$ & Not conducted & Smooth muscular cells \\
\hline Desmin & Dako & D33 & $1: 50$ & Not conducted & Muscular cells \\
\hline S-100 $(\alpha, \beta)$ & Dako & Polyclonal & $1: 500$ & Not conducted & Schwann cells, adipocytes \\
\hline ER & Novocastra & 6 F11 & $1: 40$ & $115^{\circ} \mathrm{C}$ for $10 \mathrm{~min}$ & Estrogen receptor \\
\hline $\operatorname{PgR}$ & Biodesign & $10 \mathrm{~A} 9$ & $1: 50$ & $115^{\circ} \mathrm{C}$ for $10 \mathrm{~min}$ & Progesterone receptor \\
\hline
\end{tabular}

${ }^{1)}$ ER, estrogen receptor $\alpha$; PCNA, proliferation cell nuclear antigen; PgR, progesterone receptor; SMA, $\alpha$-smooth muscle actin

${ }^{2)}$ Biodesign (Saco, ME, USA), Dako (Carpinteria, CA, USA), Leica Biosystems (Newcastle upon Tyne, UK), Novocastra (Newcastle upon Tyne, UK) ${ }^{3)}$ Primary antibodies were incubated with tissue samples for $1 \mathrm{hr}$ at room temperature, with the exception of ER antibody, which was incubated overnight at $4^{\circ} \mathrm{C}$. The antigen-antibody complexes were identified by using a streptavidinbiotin (LSAB) staining kit (Dako) according to the manufacturer's instructions. The reaction products were visualized with 3-3'-diaminobenzidine tetrahydrochloride. ${ }^{4)}$ Antigen retrieval was conducted by pressure-cooker heating (Pascal, Dako).

Gy; Oriental Yeast, Chiba, Japan) and tap water ad libitum.

The rats were anesthetized with isoflurane (Forane ${ }^{\circledR}$; Abbott Japan, Tokyo, Japan), sacrificed by exsanguinations via abdominal aortic transection, and subjected to complete necropsies. One small mammary carcinoma was seen in Case 1, but none were seen in Case 2. No abnormalities were observed except in the mammary glands macroscopically. The uterus and other reproductive organs were fixed overnight in $10 \%$ neutral buffered formalin. Samples of uterine nodules, the other uterine horns, vaginas, and ovaries were embedded in paraffin, sectioned, and stained with hematoxylin and eosin (HE). Sequential sections of nodules were stained with periodic acid Schiff (PAS). Immunohistochemistry was performed with antibodies to proliferating cell nuclear antigen (PCNA) to detect the proliferative activity ${ }^{14}$, pancytokeratin (CK) as an epithelial cell marker, vimentin as a mesenchymal cell marker ${ }^{15}$, the common acute lymphoblastic leukemia antigen $10(\mathrm{CD} 10)$ as a uterine interstitial cell marker ${ }^{16}, \alpha$-smooth muscle actin (SMA) and desmin as muscular cell markers ${ }^{15}$, S-100 as a Schwann cell and adipocyte marker ${ }^{17}$, and estrogen receptor $\alpha(E R)$ and progesterone receptor (PgR) to detect steroid hormone receptors ${ }^{18}$. Detailed staining protocols for all antibodies are listed in Table 1. Briefly, sections were deparaffinized, hydrated, and blocked for endogenous peroxidase. Heat-induced epitope retrieval was performed for all antibodies except SMA, desmin, and S-100. The antigen-antibody complexes were identified by using a streptavidin-biotin (LSAB) staining kit (Dako) according to the manufacturer's instructions. The reaction products were visualized with 3-3'-diaminobenzidine tetrahydrochloride. The intensity of immune staining was scored as negative $(-)$, weak $(+)$, moderate $(++)$, or strong $(+++)$. Histopathological examination including immunohistochemical scoring was conducted by two toxicologic pathologists certified by the Japanese Society of Toxicologic Pathology and/or the International Academy of Toxicologic Pathology (A. T. and K.Y.), according to the previously defined histopathological terminology and diagnostic criteria (goRENI, http://www.goreni.org/; Leininger and Jokinen, 1990).

A solitary uterine nodule was detected in only one rat of approximately 100 animals used in each study. The white and firm solitary nodules were found in both rats at the base of unilateral uterine horns and were approximately $6 \mathrm{~mm}$ and $4 \mathrm{~mm}$ in diameter. Histopathologically, these nodules had collapsed the uterine lumens with erosion of the overlying endometrial surface and hemorrhage (Fig. 1a, 1b). The nodules contained 3 areas of different proliferating cell types. Large epithelioid giant cells with round nuclei containing coarsely vesicular chromatin in large oval nuclei with one to four variably shaped nucleoli and abundant eosinophilic and coarsely granular cytoplasm proliferated in the antimesometrial side of the uterus (decidual cells) (Fig. 2a). Occasionally, multinucleate or binucleate cells were seen in this region. A small number of large cells possessed abundant PAS-positive granules in this region (data not shown). The mesometrial region contained pleomorphic and spiny cells with round to oval nuclei and abundant coarse clear cytoplasmic vacuoles (Fig. 2c). Small spindleshaped cells with oval nuclei and finely vacuolar cytoplasm were located between both regions (transitional region) (Fig. $2 b)$. These cells proliferated in sheet-like arrangements and transformed into the other cell types located in surrounding regions. The cells of the nodules were supported by a fine fibrovascular stroma with small congested blood vessel profiles (Fig. 2c). On the antimesometrial side, there was an expansile, partially encapsulated nodular mass composed of three poorly defined layers: the capsule, the basal zone with residual endometrial glands, and the myometrium (Fig. 2d). No abnormal changes were detected histopathologically in the other uterine horns, vaginas, and bilateral ovaries of these rats (data not shown).

The results of the immunohistochemical analysis are summarized in Table 2. The nuclei of most decidual cells in both rats were strongly positive for PCNA in all three regions (Fig. 3a), showing highly proliferative activity of the nodules. The tumor cells in all regions were also strongly positive for vimentin, and the cytoplasm of large decidual 

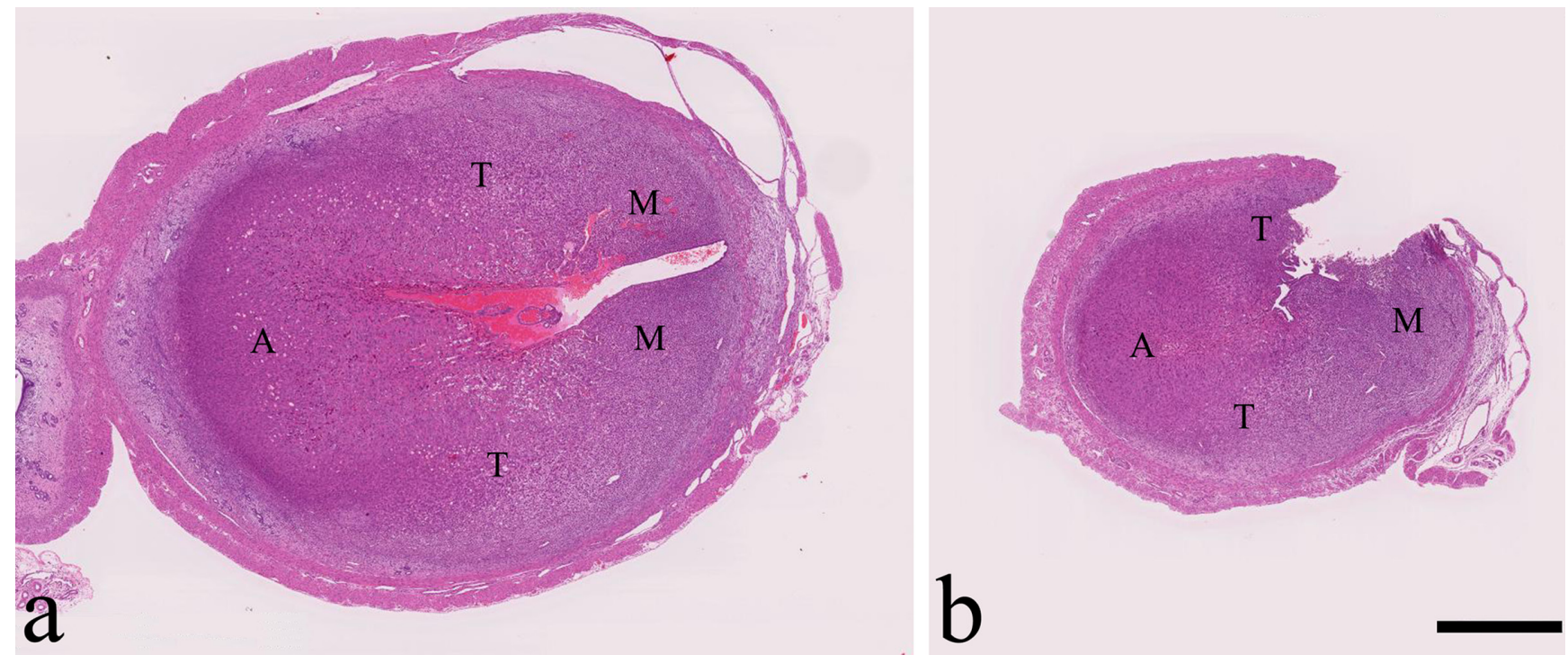

Fig. 1. Solitary nodules in the uterus of Case 1, a 15-week-old Lewis rat, (a) and Case 2, a 7-week-old SD rat (b). Note the collapsed uterine lumens. The antimesometrial region (A), transitional region $(\mathrm{T})$, and mesometrial region $(\mathrm{M})$ are shown. HE stain, bar $=1 \mathrm{~mm}$.
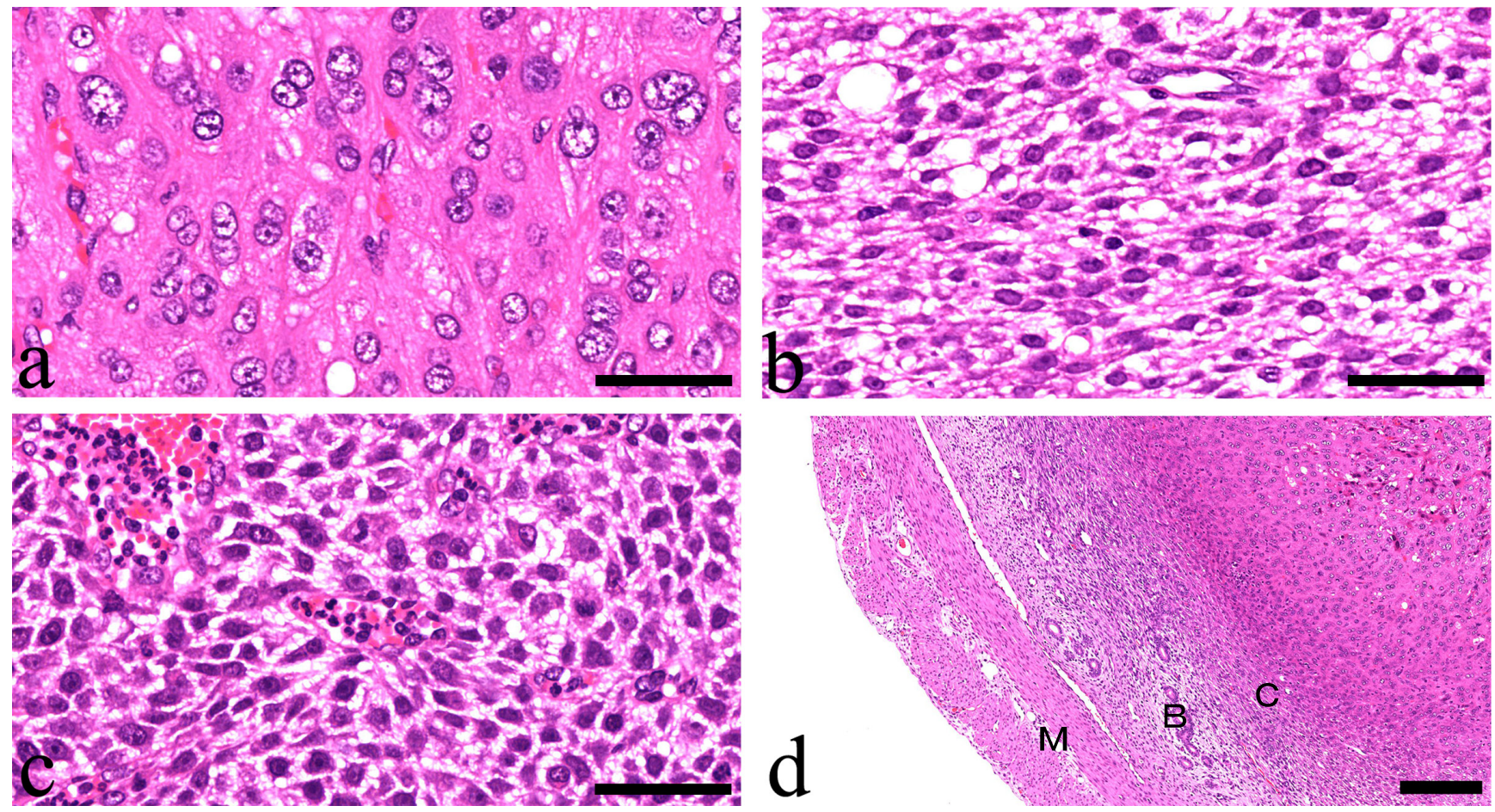

Fig. 2. Histopathological findings. (a) Large epithelial-like decidual cells can be seen in the antimesometrial region. Case 1 , HE stain, bar $=50$ $\mu \mathrm{m}$. (b) Spindle cells with vacuolar cytoplasm and prominent intercellular spaces can be seen in the transitional region. Case 1, HE stain, bar $=50 \mu \mathrm{m}$. (c) Starry-formed and spiny cells with vacuolar cytoplasm cam be seen in the mesometrial region. Case 2, HE stain, bar = $50 \mu \mathrm{m}$. (d) The outside of this nodule is composed of the myometrium (M), basal zone (B), and capsule (C). A residual endometrial gland can be seen in the basal zone. Case 1 , HE stain, bar $=200 \mu \mathrm{m}$.

cells was weakly positive for CD10, showing that the tumor cells originated from uterine interstitial cells (Fig. 3b). The cytoplasm of these cells was also moderately or strongly positive for SMA and desmin, probably suggesting differentiation into muscular cells (Fig. 3c, 3d). ER was expressed weakly to strongly in the nuclei of compact spindle-shaped cells and starry-formed cells in the transitional and mesometrial regions (Fig. 3e); however, no signals were seen in the antimesometrial region. In contrast, $\mathrm{PgR}$ was expressed moderately to strongly in the nuclei of all types of decidual 
Table 2. Immunohistochemical Expression of Antigens in the Nodules

\begin{tabular}{|c|c|c|c|c|c|c|}
\hline \multirow{2}{*}{$\begin{array}{l}\text { Primary } \\
\text { antibody }\end{array}$} & \multicolumn{3}{|c|}{ Case 1} & \multicolumn{3}{|c|}{ Case 2} \\
\hline & $\begin{array}{c}\text { Antimesometrial } \\
\text { region }\end{array}$ & $\begin{array}{l}\text { Transitional } \\
\text { region }\end{array}$ & $\begin{array}{l}\text { Mesometrial } \\
\text { region }\end{array}$ & $\begin{array}{c}\text { Antimesometrial } \\
\text { region }\end{array}$ & $\begin{array}{l}\text { Transitional } \\
\text { region }\end{array}$ & $\begin{array}{l}\text { Mesometrial } \\
\text { region }\end{array}$ \\
\hline PCNA & $+++{ }^{2)}$ & +++ & +++ & +++ & +++ & +++ \\
\hline Pancytokeratin & - & - & - & - & - & - \\
\hline Vimentin & +++ & +++ & +++ & +++ & +++ & +++ \\
\hline CD10 & + & - & - & + & - & - \\
\hline SMA & + & - & - & ++ & - & - \\
\hline Desmin & + & - & - & +++ & - & - \\
\hline $\mathrm{S}-100(\alpha, \beta)$ & - & - & - & - & - & - \\
\hline ER & - & ++ & +++ & - & + & +++ \\
\hline PgR & ++ & ++ & +++ & ++ & ++ & +++ \\
\hline
\end{tabular}

${ }^{1)}$ ER, estrogen receptor $\alpha$; PCNA, proliferation cell nuclear antigen; PgR, progesterone receptor; SMA, $\alpha$-smooth muscle actin.

2) The intensity of staining was scored as negative $(-)$, weak $(+)$, moderate $(++)$ or strong $(+++)$.
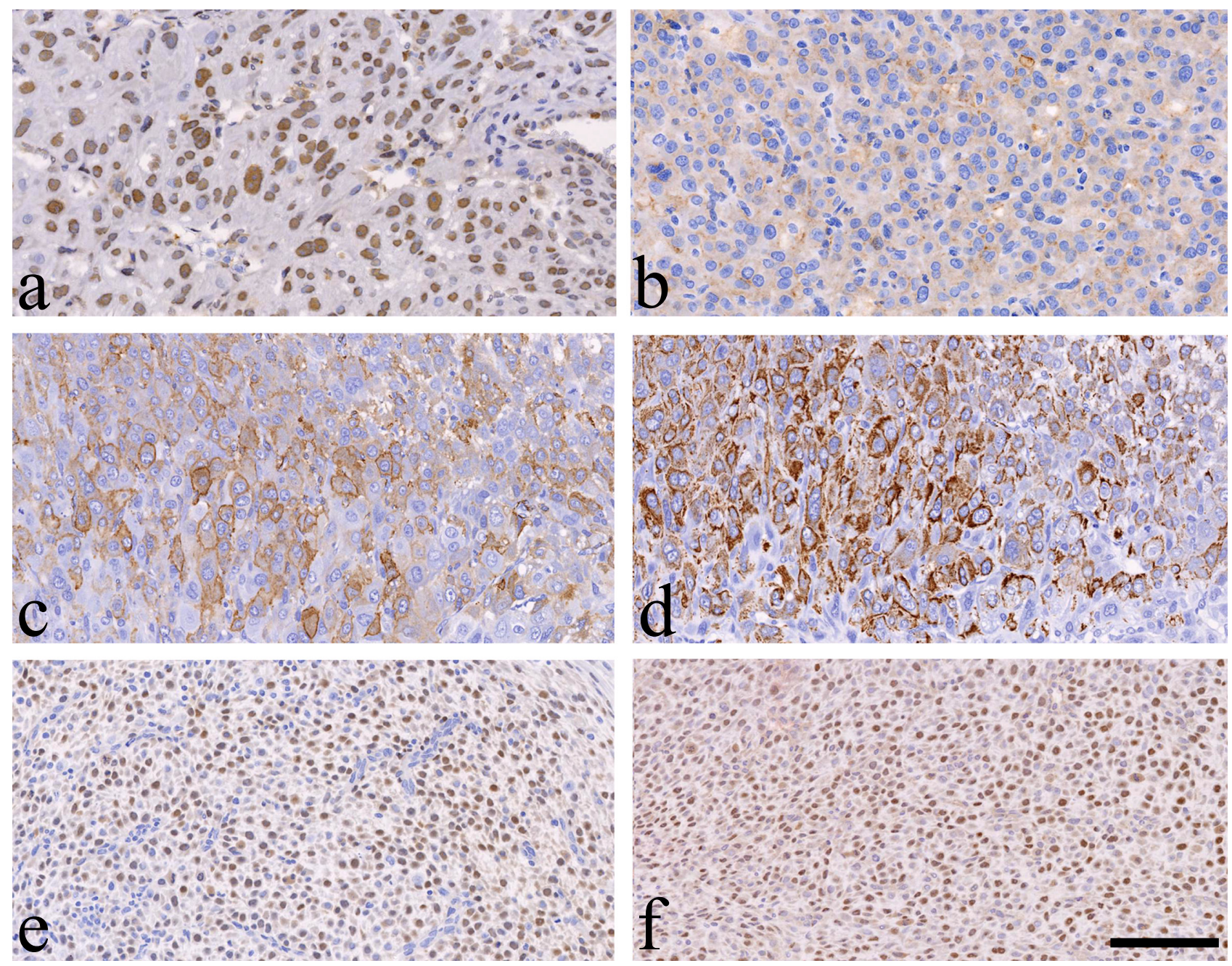

Fig. 3. Immunohistochemical characteristics. PCNA signals can be seen in most nuclei of the decidual cells in the antimesometrial region of Case 2 (a). CD10 is expressed weakly in the cytoplasm of the decidual cells in the antimesometrial region of Case 1 (b). The cytoplasm of decidual cells is moderately to strongly positive for SMA (c) and desmin (d) in the antimesometrial region of Case 2. The nuclei of most proliferative cells are diffusely positive for ER (e) and PgR (f) in the mesometrial region of Case 1. Bar $=100 \mu \mathrm{m}$.

cells in the three regions (Fig. 3f). No proliferative cells were positive for S-100 in any regions. The cells comprising the capsule and myometrium were weakly to moder- ately positive for vimentin, SMA, desmin, ER, and PgR. Endometrial glands in the basal zone were positive for CK and ER, which was similar to the normal endometrial gland 
(data not shown).

In two virgin rats, single and discrete round nodules were located in the unilateral uterine horns. They had a high level of structural organization due to the proliferation of large epithelioid cells with large round nuclei, prominent nucleoli and abundant eosinophilic cytoplasm, which are the characteristics typical of decidual cells. Histopathological findings revealed hyperplasia of decidual stromal cells, referred to as decidual reactions/deciduomas, in the rodent uterus ${ }^{2,19}$. Spontaneously occurring deciduoma is infrequently seen in young adult rats. Deciduomas can be induced in rats by mechanical irritation or trauma; electrical stimulation; intrauterine instillation of sesame oil, Hank's balanced salt solution, histamine, air, or prostaglandins; and the administration of progestin ${ }^{13,20}$. In rats, the life history of an artificially induced deciduoma may be divided into three stages: (1) proliferation of stromal cells and their differentiation into decidual cells during days 4 to 8 of pseudopregnancy; (2) maintenance of the deciduoma, a stage in which there is no further increase in decidual weight, during days 9 to 11 of pseudopregnancy; and (3) regression of the decidual tissue during days 12-16 of pseudopregnancy ${ }^{21}$. The life cycle of spontaneously occurring deciduomas is not different from the induced lesions ${ }^{13}$. Our two cases are considered to be spontaneously occurring lesions because the rats had no history of mechanical irritation or trauma to the uterus or systemic hormonal effects and the lesions were detected in only one of approximately one hundred rats used in each study.

Immunohistochemically, the expression of vimentin and desmin increases in rat decidual cells in both in vitro and in vivo models, as these proteins are valid markers of stromal cell differentiation ${ }^{22,23}$. During the implantation stage of the normal rat pregnancy, the localization of vimentin is widespread in decidual cells, while desmin is present densely in decidual cells of the antimesometrial region where implantation occurs ${ }^{24}$. In our cases, the proliferative decidual cells showed strong and diffuse expression of vimentin; however, desmin was expressed in the decidual cells in the antimesometrial region. Similar to the expression of desmin, SMA was expressed in the decidual cells of the antimesometrial region, suggesting myogenic or myofibroblastic differentiation ${ }^{25}$. In our deciduomas, large decidual cells at the antimesometrial region also weakly expressed CD10, a marker for uterine interstitial cells ${ }^{16,26}$. Although normal endometrial stromal cells are positive for CD10 in humans ${ }^{16}$, these signals were not detected in the normal endometrial stromal cells in rats.

ER and $\mathrm{PgR}$ are expressed in the myometrium of the rat during the decidualization process and in spontaneously occurring deciduomas ${ }^{21}$. Progesterone and small amounts of estrogen are required for the sensitization of the uterus before a decidualizing stimulus. Continuous presence of progesterone is essential and adequate for proliferation of the decidual cells and for the growth and maintenance of the deciduoma ${ }^{21}$. In our cases, PgR and ER were expressed strongly in the mesometrial region; however, ER was not ex- pressed in the antimesometrial region. According to a previous report ${ }^{27}$, the involvement of both receptors may suggest that as the decidual cells become differentiated, they become enriched in PgR and impoverished in ER.

Although Lewis rats and SD rats are frequently used in pharmacological studies and toxicity studies, respectively, historical control data for uterine decidual lesions in young rats of both strains have not been well reported. In our cases, proliferating decidual cells expressed PCNA, vimentin, CD10, SMA, and desmin. PgR was expressed in all cell types, but ER was not expressed in the antimesometrial region. Although additional immunohistochemical analyses are needed to understand the biology of spontaneously occurring deciduomas, our two cases might provide valuable information as a historical control for Lewis and SD rats.

Acknowledgement: This study was supported in part by a Grant-in Aid for Scientific Research C from the Japan Society for the Promotion of Science (22591954). We thank Ms. T. Akamatsu for her technical assistance and Dr. T. Sasaki, Maruho Co. Ltd., for her excellent scientific advice. All authors read and approved the final manuscript. We declare that we have no competing financial interests.

\section{References}

1. Bryant CM. Wednesday Slide Conference 2009-2010 Conference 7. The Armed Forces Institute of Pathology, Department of Veterinary Pathology. 1-6. 2009.

2. Leininger JR, and Jokinen MP. Oviduct, uterus and vagina. In: Pathology of the Fischer Rat: Reference and Atlas. Boorman GA, Eustis SL, Elwell MR, Montgomery Jr. CA, and MacKenzie WF (eds.). Academic Press, London. 450-452. 1990.

3. Davis BJ, Dixon D, and Herbert RA. Decidual reaction. In: Pathology of the Mouse. Ovary, Oviduct, Uterus, Cervix, and Vagina. Maronpot RR, Boorman GA, and Gaul BW (eds). Cache River Press, Vienna. 436. 1999.

4. Karbe E. "Mesenchymal tumor" or "decidual-like reaction"? Toxicol Pathol. 27: 354-362. 1999. [Medline] [CrossRef]

5. Mitchell JA, and Garris DR. Deciduoma formation in response to uterine trauma in the guinea pig. Biol Reprod. 19: 1135-1141. 1978. [Medline] [CrossRef]

6. Cooper TK, Adelsohn D, and Gilbertson SR. Spontaneous deciduosarcoma in a domestic rabbit (Oryctolagus cuniculus). Vet Pathol. 43: 377-380. 2006. [Medline] [CrossRef]

7. Koguchi A, Nomura K, Fujiwara T, Kawai Y, and Okaniwa A. Maternal placenta-like endometrial hyperplasia in a beagle dog (Canine deciduoma). Exp Anim. 44: 251-253. 1995. [Medline] [CrossRef]

8. Ghosh D, Bell SC, and Sengupta J. Immunohistological localization of insulin-like growth factor binding protein-1 in primary implantation sites and trauma-induced deciduomal tissues of the rhesus monkey. Placenta. 25: 197-207. 2004. [Medline] [CrossRef]

9. Carter D, True L, and Otis CN. Serous membranes. In: Histopathology for Pathologists. Mills SE (ed). Lippincott Williams \& Wilkins, Philadelphia. 559, 2007. 
10. Hendrickson MR, Atkins KA, and Kempson RL. Uterus and fallopian tubes. In: Histopathology for Pathologists. Mills SE (ed). Lippincott Williams \& Wilkins, Philadelphia. 559. 2007.

11. Dunn CL, Kelly RW, and Critchley HO. Decidualization of the human endometrial stromal cell: an enigmatic transformation. Reprod Biomed Online. 7: 151-161. 2003. [Medline] [CrossRef]

12. Dixon D, Heider K, and Elwell MR. Incidence of nonneoplastic lesions in historical control male and female Fischer-344 rats from 90-day toxicity studies. Toxicol Pathol. 23: 338-348. 1995. [Medline] [CrossRef]

13. Elcock LH, Stuart BP, Mueller RE, and Hoss HE. Deciduoma, uterus, rat. In: Monographs on Pathology of Laboratory Animals: Genital System. Jones TC, Mohr U, and Hunt RD (eds). Springer-Verlag, Berlin. 140-145. 1987.

14. Sasaki T, Yoshizawa K, Kinoshita Y, Miki H, Kimura A, Yuri T, Uehara N, and Tsubura A. Spontaneous occurring intracranial lipomatous hamartoma in a young BALB/c mouse and a literature review. J Toxicol Pathol. 25: 179182. 2012. [Medline]

15. Yoshizawa K, Oishi Y, Makino N, Suzuki J, Matsumoto M, Fukuhara Y, Fujihira S, and Fujii T. Congenital mesoblastic nephroma in a young beagle dog. J Toxicol Pathol. 9: 101-105. 1996. [CrossRef]

16. Toki T, Shimizu M, Takagi Y, Ashida T, and Konishi I. CD10 is a marker for normal and neoplastic endometrial stromal cells. Int J Gynecol Pathol. 21: 41-47. 2002. [Medline] [CrossRef]

17. Yoshizawa K, Oishi Y, Makino N, Suzuki J, Matsumoto M, Yamauchi K, Fujihira S, and Fujii T. Malignant schwannoma of the intracranial trigeminal nerve in a 19-week-old female Sprague-Dawley rat. J Toxicol Pathol. 9: 107-112. 1996. [CrossRef]

18. Yuri T, Lai YC, Kanematsu S, Kuwata M, Yoshizawa K, and Tsubura A. Effects of short-term estrogen treatment on the progression of $\mathrm{N}$-methyl- $\mathrm{N}$-nitrosourea-induced prema- lignant mammary lesions in female Lewis rats. Med Mol Morphol. 44: 125-130. 2011. [Medline] [CrossRef]

19. goRENI. Global Open Registry Nomenclature Information System. http://www.goreni.org/.

20. Finn CA, and Keen PM. The induction of deciduomata in the rat. J Embryol Exp Morph. 11: 673-682. 1963. [Medline]

21. Peleg S, Bauminger S, and Lindner HR. Oestrogen and progestin receptors in deciduoma of the rat. J Steroid Biochem. 10: 139-145. 1979. [Medline] [CrossRef]

22. Glasser SR, and Julian J. Intermediate filament protein as a marker of uterine stromal cell decasualization. Biol Reprod. 35: 463-474. 1986. [Medline] [CrossRef]

23. Glasser SR, Lampelo S, Munir MI, and Julian J. Expression of desmin, laminin and fibronectin during in situ differentiation (decidualization) of rat uterine stromal cells. Differentiation. 35: 132-142. 1987. [Medline] [CrossRef]

24. Korgun ET, Cayli S, Asar M, and Demir R. Distribution of laminin, vimentin and desmin in the rat uterus during initial stages of implantation. J Mol Histol. 38: 253-260. 2007. [Medline] [CrossRef]

25. Oliver C, Montes MJ, Galindo JA, Ruiz C, and Olivares EG. Human decidual stromal cells express $\alpha$-smooth muscle actin and show ultrastructural similarities with myofibroblasts. Hum Reprod. 14: 1599-1605. 1999. [Medline] [CrossRef]

26. Klemmt PAB, Carver JG, Kennedy SH, Koninckx PR, and Mardon HJ. Stromal cells from endometriotic lesions and endometrium from women with endometriosis have reduced decidualization capacity. Fertil Steril. 85: 564-572. 2006. [Medline] [CrossRef]

27. Martel D, Monier MN, Psychoyos A, and DeFeo VJ. Estrogen and progesterone receptors in the endometrium, myometrium, and metrial gland of the rat during the decidualization process. Endocrinology. 114: 1627-1634. 1984. [Medline] [CrossRef] 